\title{
RECONSTRUCTING THE SOMALI STATE: THE ROLE OF PUBLIC-PRIVATE PARTNERSHIPS
}

Yusuf Nur, Indiana University Kokomo, Kokomo, Indiana, USA Dmitriy Chulkov, Indiana University Kokomo, Kokomo, Indiana, USA Jason VanAlstine, Indiana University Kokomo, Kokomo, Indiana, USA

dx.doi.org/10.18374/JIMS-13-1.2

\begin{abstract}
This study discusses the role of the private sector and public-private partnerships (PPPs) in reconstructing the Somali state and economy. We review the historical background of the economic and political change in the Somali Republic and focus on the role of public-private partnerships in infrastructure investment and development. Statelessness in the Somali Republic has created an environment in which new business models could flourish with minimal government interference, and without competition from international firms. Empirical evidence suggests that the private sector in the Somali Republic adjusted to statelessness and created new operational models that can be tapped into in order to help the Somali Republic rebuild its state institutions and public infrastructure. This study proposes that public infrastructure investment may build on the successful business models that the Somali economy developed in recent years and argues that PPPs have a unique role to play in the reconstruction of the Somali infrastructure.
\end{abstract}

Keywords: Public-private partnerships, Infrastructure, Somalia, Public Economics, International Business. 